\title{
AKUNTANSI "HUYULA" (KONSTRUKSI AKUNTANSI KONSINYASI BERBASIS KECERDASAN INTELEKTUAL, EMOSIONAL, SPIRITUAL DAN SOSIAL)
}

\author{
"HUYULA" ACCOUNTING (CONSTRUCTION ACCOUNTING BASED ON \\ INTELLECTUAL, EMOTIONAL, SPIRITUAL AND SOCIAL INTELLIGENCE)
}

\author{
Mohamad Anwar Thalib \\ Institut Agama Islam Negeri Sultan Amai Gorontalo \\ mat@iaingorontalo.ac.id
}

\begin{abstract}
Abstrak
Tujuan penelitian ini adalah untuk mengkonstruksi akuntansi konsinyasi berbasis IESSQ. Paradigma yang digunakan oleh penelitian ini adalah spiritualis. Etnometodologi Islam dipilih sebagai pendekatan untuk mengkonstruksi akuntansi konsinyasi. Terdapat lima tahapan analisis data yaitu amal, ilmu, iman, informasi wahyu dan ihsan. Hasil penelitian menemukan bahwa praktik akuntansi konsinyasi berawal dari kecerdasan spiritual (SQ) berupa tolong-menolong. Kecerdasan spiritual ini kemudian membentuk rasa (kecerdasan emosional/EQ) belas asih, amanah dan tolong menolong. Kecerdasan intelektual (IQ) dari praktik akuntansi konsinyasi berupa menerima, menjual dan mendapatkan keuntungan merupakan bentukan dari SQ dan EQ. IESQ pada akhirnya menggiring terbentuknya amal sosial (kecerdasan sosial/SQ) yaitu praktik akuntansi konsinyasi berbasis nilai tolong-menolong (huyula).
\end{abstract}

Kata Kunci: Akuntansi, Konsinyasi, Gorontalo, Huyula

\begin{abstract}
The purpose of this study is to construct consignment accounting based on IESSQ. This research uses spiritual paradigm. Islamic ethnometodology is chosen as an approach to construct consignment accounting. There are five of data analysis stages; amal, ilmu, iman, informasi wahyu and ihsan. The result of study found that consignment accounting practice comes from spiritual intelligence (SQ) that is help each other. it constructs feeling (emosional intelligence/EQ) about compassion, trusteeship and help. Intellegtual intelligence (IQ) of consignment accounting practice are receiving, selling, and getting profit. In the end, the third of intelligences construct social charity (social intelligence) that is consignment accounting based on mutual help value (huyula).
\end{abstract}

Keywords: accounting, consignment, Gorontalo, Huyula

\section{PENDAHULUAN}

Akuntansi modern membagi gaya pencatatan konsinyasi menjadi dua yaitu netto dan bruto. Patut untuk digaribawahi bahwa kedua metode pencatatan hanya merekam transaksi yang bersifat materi (uang) dan mengabaikan hal-hal yang bersifat non materi. Hal ini disebabkan karena akuntansi konsinyasi yang hadir sekarang merupakan hasil racikan dari akuntansi modern yang hidup dengan ruh modernitas. Oleh sebab itu tidaklah mengherankan realitas yang diakui dan direkam oleh akuntansi konsiyasi saat ini hanya sebatas pada hal-hal materi saja (uang).

Kurang tepat dan lengkapnya akuntansi konsinyasi yang dipraktikkan sekarang baru akan terlihat jika kita mau melihatnya dari sudut pandang yang berbeda (bukan dari sudut pandang akuntansi modern). Misalnya saja dari hakikat penciptaan manusia di muka bumi. Ya, dilihat dari sudut pandang keimanan tentang tujuan penciptaan manusia, apa yang disajikan oleh akuntansi konsinyasi menjadi kurang tepat. Kurang tepatnya akuntansi (konsinyasi) disebabkan oleh nilai matrealitas, egoisme dan utilitarian(Ahmar \& Kamayanti, 2009; Amaliah, 2014; Martadinata, 2015; Randa, Triyuwono, Ludigdo, \& Sukoharsono, 2011; Thalib, 2014, 2016, 2017; Thalib \& Prasindi, 2016; Triyuwono, 2011c, 2011a, 2015b, 2015a, 2006a, 2006b; Wiyarni, Triyuwono, Ludigdo, \& 
Djamhuri, 2013). Keegoisan akuntansi konsinyasi dapat dilihat dari maraknya teori/konsep dan juga praktik akuntansi konsinyasi yang membahas keuntungan sebatas untuk penitip dan pemilik saja. Sementara itu, pihak yang tidak berhubungan langsung dengan pemilik dan penitip seolah tidak berhak untuk mendapatkan keuntungan, salah satu contoh pihak lain tersebut adalah alam, masyarakat sekitar bahkan Tuhan ${ }^{1}$.

Nilai utilitarianisme juga menjadi nyawa berikutnya yang hadir dalam akuntansi konsinyasi. Hal ini dapat dilihat dari cara pemberian bonus pihak yang menitipkan kepada pihak yang tertitip.Pihak yang menitipkan barang hanya akan memberikan bonus kepada yang dititipkan barang apabila ia berhasil menjual barang tersebut. Jika barang-barang yang dititipkan tidak terjual, maka secara otomatis pihak yang dititipkan barang tidak akan menerima bonus dari pihak yang menitipkan barang. Dari kejadian ini dapat dilihat manfaat dari hasil akhirlah yang menjadi tumpuan pemberian bonus, manfaat hasil akhir ini merupakan karakteristik dari nilai utilitarian. Mungkin akan ada yang bertanya, mengapa nilai utilitarian menjadi kurang tepat dengan hakikat penciptaan manusia dalam hal ini beribadah? Hal ini disebabkan karena bisa saja proses menuju hasil akhir dari penjualan barang-barang konsinyasi tersebut bertentang dengan nilai-nilai kemanusiaan dan juga keimanan. Sehingga tidaklah berlebihan mengatakan bahwa tolak ukur pemberian bonus berdasarkan jumlah penjualan (dan mengabaikan prosesnya) menjadikan akuntansi konsinyasi sekarang kurang tepat.

Sementara itu, untuk nilai matrealisme tercermin dari pencatatan akuntansi konsinyasi yang sebatas hal-hal yang berhubungan dengan materi (uang) dan mengabikan hal-hal yang bersifat non materi. Ketiga nilai akuntansi konsinyasi berupa matrealisme, egoisme dan utilitarianisme pada akhirnya menciptakan bentuk yang kurang lengkap dari akuntansi konsinyasi. Kurang lengkapnya bentuk informasi dari akuntansi konsiyasi tersebut terletak pada tidak hadirnya informasi yang memuat hal-hal yang bergubungan dengan emosional, spiritual, dan sosial. Akuntansi konsiyasi hanya menyajikan informasi materi yang berhubungan dengan kecerdasan intelektual saja.

Pentingkah mengakomodir informasi yang bersifat emosional, spiritual dan sosial dalam akuntansi konsinyasi? Tentu saja ketiga informasi non materi tersebut menjadi penting karena informasi tersebut berhubungan dengan kesadaran tentang hakikat manusia di dunia (Ludigdo, 2004; Mulawarman., Aji Dedi, Ludigdo, 2010; Triyuwono, 2011b). Selama ini kesadaran yang terbangun dari pengguna informasi akuntansi hanya sebatas pada materi (uang). Hal ini disebabkan karena akuntansi hanya mengakomodir hal-hal yang berhubungan dengan materi saja. Diperlukan informasi non materi berupa emosional, spiritual dan sosial agar kesadaran pengguna akuntansi konsinyasi menjadi lebih menyeluruh/lengkap. Kelengkapan informasi akuntansi tersebut pada akhirnya dapat membawa kesadaran tentang hakikat penciptaan manusia yaitu beribadah kepadaNya.

Berpijak pada penjelasan di atas tentang kurang tepat dan lengkapnya akuntansi konsinyasi sekarang menjadi dasar untuk mengadakan penelitian ini. Rumusan masalah yang diangkat oleh penelitian ini adalah bagaimanakah pedagang pasar tradisional mempraktikkan akuntansi konsinyasi? Berangkat dari rumusan masalah tersebut maka yang menjadi tujuan penelitian ini adalah untuk mendekonstruksi akuntansi konsinyasi berbasi kecerdasan intelektual, emosional, spiritual dan sosial.

\section{METODE}

Penelitian ini menggunakan paradigma spiritualis. Pemilihan peradigma spiritualis disebabkan asumsi dasar paradigma ini lebih holistik dibandingkan dengan paradigma lainnya (positive, interpretif, kritis dan posmodern) (Kamayanti, 2015b, 2015a, 2016; Kuntowijoyo, 2007; Mulawarman, 2013; Sardar, 1985; Thalib, 2017; Triyuwono, 2015a, 2011a, 2011b, 2013). Metode yang digunakan penelitian ini adalah kualitatif dengan pendekatan etnometodologi Islam. Etnometodologi Islam dipilih sebagai pendekatan disebabkan tujuan penelitian ini adalah untuk menggungkap cara praktik akuntansi konsinyasi yang holistik sehingga etnometodologi modern menjadi kurang tepat (Thalib, 2017). Sementara itu penelitian ini juga menggunakan alat analisis data etnometodologi Islam yang dirangkai oleh Thalib. Alat analisis itu adalah amiiin. Amiiin

\footnotetext{
${ }^{1}$ Lihat juga (Thalib \& Prasindi, 2016; Triyuwono, 2011b)
} 
merupakan singkatan dari amal, ilmu, iman, informasi wahyu dan ihsan (Thalib, 2017). Berpijak pada hasil dari analisis data tersebut maka kemudian penulis mengkonstruksi akuntansi berbasis IESSQ.

Lokasi penelitian ini berada di Indonesia, tepatnya provinsi Gorontalo, Kabupaten Bone Bolango, Kecamatan Tapa, Desa Talumopatu. Di desa ini terdapat pasar tradisional yang disebut dengan pasar Kamis Tapa. Sebenanya pasar ini beroperasi dua kali dalam seminggu yaitu hari Senin dan Kamis. Namun warga sekitar lebih akrap menyebut tempat ini dengan nama pasar Kamis Tapa. Pemilihan lokasi disebabkan oleh provinsi Gorontalo merupakan salah satu provinsi yang memiliki ciri khas nilai budaya yang didasarkan pada nilai-nilai agama Islam. Hal ini terlihat lewat filosofi daerah tersebut berupa adat bersendikan syarah, syarah bersendikan kitabullah (alquran dan hadis)/ Adat berdasarkan syariat, dan syariat berdasarkan pada Alquran dan Hadis (Botutihe \& Daulima, 2003; Daulima, 2004, 2006; Jasin, 2015; Thalib, 2016; Yunus, 2013).

Alasan berikutnya adalah kemudahan mengakses lokasi penelitian disebabkan peneliti bertempat tinggal disekitar lokasi penelitian. Kemudahan menjangkau lokasi penelitian menjadi alasan penting disebabkan dengan mudahnya peneliti menjangkau lokasi semakin memungkinkan data yang didapatkan untuk penelitian ini semakin lengkap dan detail. Informan dalam penelitian ini berjumlah tiga orang yaitu $t a$ Meri, $t a$ Tini dan $t a$ Nou. Pemilihan ketiga informan didasarkan pada; pertama para informan merupakan pedagang pasar Kamis Tapa yang telah berdagang lebih dari sepuluh tahun. Kedua, para pedagang tidak saja menjual barang dagangan mereka sendiri namun juga barang titipan dari penjual lainnya. Ketiga para pedagang bersedia untuk meluangkan waktu mereka untuk dimintakan informasi mengenai cara praktik akuntansi konsinyasi yang mereka lakukan.

\section{HASIL DAN PEMBAHASAN}

Salah satu hal menarik yang terdapat pada pasar Kamis Tapa adalah tidak semua kue yang dijual oleh para penjual merupakan kue buatan mereka sendiri. Dengan kata lain ada beberapa pembuat kue yang tidak langsung menjual kue mereka namun memilih untuk menitipkan kue tersebut di tempat penjual kue berjualan. Fenomena tersebut tentu menarik karena selama ini ekonomi (termasuk akuntansi) modern selalu menyuguhkan kita dengan santapan paham utilitarianisme, paham yang mengatas namakan kebenaran pada kebermanfaatan, jika tidak bermanfaat maka tentu hal itu tidak perlu dilakukan atau bahkan dimusnahakan saja. Artinya jika berdagang kita bertemu dengan sesuatu yang mengurangi keuntungan kita misalnya pesaing, maka sikap yang benar menurut paham ini adalah menghindari atau bahkan "menghabisi". Contoh sederhananya dapat kita jumpai pada iklan produk yang saling sindir atau bahkan menjelekjelekkan pesaingnya.

Hal berseberagan justru terjadi, para penjual kue di pasar tradisional, mereka justru menerima titipan kue dari para pembuat kue lain (atau dalam ekonomi modern dikatakan pesaing). Pertanyaan sekarang adalah "apa motif yang mendasari tindakan mereka tersebut? Apakah hal ini dilakukan atas dasar keuntungan berupa uang? Sebagaimana yang digambarkan oleh ekonomi (akuntansi) modern, atau justru ada nilai-nilai penggerak lainnya? Cuplikan wawancara ta Tini di bawah ini merupakan jawaban pengantar dari kedua pertanyaan tersebut.

Mo tarima ka sana, tidak bole mo ba tolak rejeki, bomo taru ka sana, bo sapa yang kalau suka itu, kita tidak mo ba bilang, ah ini dia mo suru jual saribu, baru kita mo suru jual saribu barapa, tidak bo tetap saribu, tidak ada yang kita mo ini bagitu, mo abis, mo abis dorang punya, kalau bo dua pulu biji itu kasing so barapa, tidak ada yang dorang mo titip banya-banya, bo dua pulu kita somo tarima ka sana. Kalau somo ini kamari ati, so sombong dia ini, ah itu yang kita mo jaga "ma didu mowali po titipua lo kukisi" ah itu yang kita mo jaga, mo laku dengan tidak taru saja, alhamdulillah debo mo laku ati.

Akan diterima, tidak boleh menolak rejeki. Hanya diletakan juga kan, siapa [pembeli] yang suka itu. Saya tidak akan mengatakan, ah ini [penitip] kue minta dijual seribu lalu saya minta dijual seribu lebih, tidak, tetap seribu, saya tidak 
seperti itu, habis ataupun tidak habis, kalau misalnya hanya dua puluh biji kue kasian sudah berapa [untungnya mereka]. Mereka tidak menitip kue dalam jumlah yang banyak. "Dia itu sudah sombong" ah itu juga yang harus saja jaga "sudah tidak bisa dititipkan kue" [perkataan itu] yang saya jaga, laku ataupun tidak, silahkan di titipkan saja. Alhamdulillah tetap laku kasian.

Cuplikan wawancara ta Tini di atas memberikan saya pemahaman bahwa beliau merima titipan kue dengan alasan tidak boleh menolak rejeki, lagi pula kue tersebut hanya diletakan saja di tempat beliau berjualan. Jadi tergantung pada pembeli yang menyukai kue yang mana. Beliau tidak pernah menaikan harga kue dari penitip kue, artinya jika kue tersebut harganya seribu, maka begitu pula yang akan beliau sampaikan kepada pembeli. Ditambah lagi biasanya penitip kue hanya menitipkan kue dalam jumlah yang tidak banyak sekitar dua puluh biji kue. Dan hal yang tidak kalah pentingnya adalah beliau menerima titipan kue karena menjaga hubungan silaturahim dengan penitip kue, beliau tidak mau dikatatakan sombong hanya karena menolak permintaan penitipan kue, dan beliau juga bersyukur bahwa kue-kue (baik milik beliau atau titipan) tetap laku terjual. Berpijak pada cuplikan wawancara di atas ditemukan praktik akuntansi konsinyasi yang tercermin lewat amal "Akan diterima, tidak boleh menolak rejeki". Ilmu dari amal ini adalah saya menerima permintaan tolong dari pembuat kue. Permintaan tolong berupa menjualkan kue buatan mereka dengan cara dititipkan ditempat saya. Saya mengganggap bahwa itu merupakan rejeki sehingga tidak boleh ditolak. Amal berikutnya dari praktik akuntansi konsinyasi adalah "hanya diletakan juga kan, siapa [pembeli] yang suka itu". Ilmu dari amal ini adalah kue yang dibuat oleh pembuat kue yang kemudian diminta untuk dijual di tempat jualan saya tidak banyak menguras tenaga. Hal ini disebabkan kue-kue tersebut hanya diletakan saja di meja jualan, kemudian menunggu pembeli untuk membelinya.

Amal selanjutnya yang ditemukan pada cuplikan wawancara $t a$ Tini di atas adalah " $a$ h ini [penitip] kue minta dijual seribu lalu saya minta dijual seribu lebih". Ilmu dari amal ini adalah karena kue tersebut dititipkan di tempat saya bukan berarti saya akan mengambil keuntungan. Saya tidak pernah menaikan harga untuk mendapatkan keuntungan. Jika penitip kue mengatakan kepada saya bahwa kue tersebut harganya Rp 1.000, maka begitu pula harga yang akan saya sampaikan kepada pembeli. Masih ada cuplikan wawancara yang sama ditemukan amal "Mereka tidak menitip kue dalam jumlah yang banyak". Ilmu dari amal ini adalah saya selalu menerima jika ada penitip kue yang mau menitipkan kue di tempat saya, namun biasanya jumlah kue yang mereka titipkan tidaklah banyak, sekitar duapuluh biji kue saja. Dan amal berikut yang ditemukan adalah "sudah tidak bisa dititipkan kue" [perkataan itu] yang saya jaga". Ilmu dari amal ini adalah selain karena saya mengganggap bahwa kue yang dititipkan itu merupakan rejeki, saya juga berusaha untuk menjaga hubungan silahturami dengan para penitip kue, jangan sampai mereka sakit hati ketika saya menolak menerima titipan kuenya dan mereka beranggapan bahwa saya adalah orang yang sombong.

Lebih lanjut, saya mencoba menggali tentang keuntungan yang ta Tini ambil dari tindakan menerima titipan kue, berikut tanggapan beliau:

Pokoknya, kalau ini, kita somo ambe akan kukis, kasiang juga, so barapa depe keuntungan itu, dorang mo kase 800 pa kita, kita smo ambe kukis satu, dia bilang "po hama mota", kalau kue bo dua pulu ampa pulu kasing bo barapa depe harga.hau sama-sama dengan kita dorang, kita itu sayang, tidak bole to, kita tidak mo ba ambe depe untung, bomo ba ambe ka sana kukis satu,

Pokoknya, kalau berjualan paling saya hanya mengambil kue, kasian juga, sudah berapa keuntungan dari titipan kue mereka. Mereka meminta saya 800, saya sudah mengambil kue satu biji saja. Penjual mengatakan kepada saya "silakan mengambil [beberapa keuntungan dari kue ini]". Kalau kuenya hanya dupuluh, empat puluh kasiang, sudah berapa harga [keuntungannya]. Sedangkan saya dengan mereka samasama [membutuhkan]. Saya merasa sayang. Tidak bisa kan, saya tidak mengambil untung, hanya mengambil kue satu [biji saja]. 
Cuplikan wawancara $t a$ Tini di atas menggambarkan bagaimana sikap beliau ketika pembuat kue lain menitipkan kue mereka untuk di jual di tempatnya. Dipahami bahwa walaupun beliau diminta untuk mengambil keuntungan dari kue yang dititipkan tapi ta Tini tidak sampai hati untuk melakukannya. Beliau justru merasa kasihan karena memang kue yang dititipkan jumlahnya hanya sedikit. Jika ditambah dengan beliau mengambil keuntungan dari setiap harga kue, maka berapa pedapatan yang didapatkan oleh pembuat kue tersebut? Sementara itu, mereka dalam kondisi ekonomi yang sama-sama membutuhkan, beliau hanya mengambil kue satu biji saja itupun menurut saya hanya sebagai rasa menghargai dari tawaran mengambil keuntungan yang diberikan oleh penjual.

Berpijak pada cuplikan wawancara di atas ditemukan praktik akuntansi konsinyasi yang tercermin pada amal "silakan mengambil". Amal ini memiliki pemahaman bersama (ilmu) bahwa ketika menitipkan atau dititipkan kue, kedua belah pihak telah sama-sama memahami tentang ada hal yang harus didapatkan atau diberikan oleh masing-masing pihak dalam konteks percakapan tersebut $t a$ Tini dipersilahkan oleh penitip untuk mengambil keuntungan dari kue yang dititipkan, sebagaimana pengamatan peneliti, umumnya harga kue titipan perbiji adalah Rp 800. Artinya beliau diizinkan untuk mendapatkan keuntungan $\mathrm{Rp} 200$ per biji kue karena rata-rata harga kue di pasar kamis adalah Rp 1.000.

Amal dari praktik akuntansi konsinyasi berikutnya adalah "saya tidak mengambil untung, hanya mengambil kue satu". Amal ini memiliki pemahaman bersama (ilmu) bahwa ta Tini tidak menerima tawaran untuk mengambil keuntungan berupa uang dari kue yang dititipkan oleh penjual. Namun beliau lebih memilih mengambil kue, hal ini dimaksud bukan mengambil keuntungan akan tetapi menghargai apa yang telah ditawarkan oleh penjual kepadanya. Artinya baik $t a$ Tini ataupun pembuat kue sama-sama telah mengetahui kondisi ekonomi masing-masing. Sehingga walaupun dipersilahkan untuk mendapatkan keuntungan berupa uang dari penitipan kue, namun $t a$ Tini lebih memilih untuk tidak melakukannya. Dan untuk menjaga perasaan penitip dari tindakan yang diambil ta Tini (menolak mengambil keuntungan) maka beliau mencoba menghargainya dengan mengambil satu biji kue saja. Inilah hal-hal yang tidak dijelaskan secara lugas dalam interaksi antara penitip dan penjual kue dalam mempraktikkan akuntansi konsinyasi. Namun hal tersebut telah menjadi pemahaman bersama atau singkatnya hal tersebut disebut dengan Ilmu.

Hal senada juga mirip dialami oleh ta Mery, dimana selain berjualan kue yang di buat sendiri, beliau juga sering menerima titipan kue dari pembuat kue, umumnya hal ini didasarkan karena perasaan yang tidak sampai hati untuk menolak pembuat kue menitipkan dagangan mereka, informasi lebih jelasnya dapat kita lihat pada cuplikan wawancara berikut ini:

Io ada, nasi bulu, sate. Kasing dorang so bawa kamari ati salah-salah ati. Kase titip, so perasaan kan mo bilang jangan. Bomo ba taru-taru... Bo nenek-nenek kasiang, dorang hobi skali mo bekeng lalampa. Bekeng garo, garo terbuat dari terigu ini. dorang pangge-pangge ti nenek raina bagitu.

Iya ada, nasi bulu dan sate. Kasian mereka sudah bawa kemari [ke tempat saya berjualan] salah-salah kasian. Kase titip. Tidak sampai hati untuk menolak [merek menitip kue]. Hanya di letakan [di meja jualan saya]... hanya nenek-nenek kasian, mereka memang sering membuat kue lalampa [lemper], kue roti goreng yang terbuat dari terigu. Mereka sering memanggil nenek itu dengan sebutan nenek Raina.

Cuplikan wawancara ta Mery di atas memberikan saya pemahaman bahwa ada beberapa dari jualan yang beliau jual merupakan titipan dari pembuat kue lain. Beliau menerima titipan kue tersebut disebabkan oleh rasa iba. Persasaan iba tesebut hadir karena mereka (pembuat kue) telah membawa kue -kuenya ke tempat jualan ta Meri. Oleh sebab itu, ta Meri tidak sampai hati menolak titipan kue, terlebih lagi yang menitipkan kue itu adalah orang tua. Pada cuplikan 
wawancara di atas jelas bahwa kue yang sering dititipkan oleh nenek Raina antara lain lemper dan roti goreng.

Berpijak pada cuplikan wawancara di atas ditemukan amal dari praktik akuntansi konsinyasi "Kasian mereka sudah bawa kemari [ke tempat saya berjualan] salah-salah kasian", Ilmu dari amal ini adalah cara penitip kue menitipkan kue di tempat saya adalah dengan membawa langsung kuekue titipan itu ke tempat jualan saya. Artinya saya tidak menjemput kue yang mereka buat, namun merekalah yang mengantarnya ke tempat saya. Amal selanjutnya adalah "Tidak sampai hati untuk menolak [merek menitip kue]". IImu dari amal ini adalah saya tidak sampai hati untuk menolak penitip kue yang diantaranya adalah nenek-nenek, ditambah lagi mereka telah membawa kue tersebut langsung ke meja jualan saya. Amal berikutnya adalah "Hanya diletakan [di meja jualan saya]..." ilmu dari amal ini adalah kue-kue tersebut diletakan di meja saya berjualan, bersampingan dengan kue-kue yang saya jual, dan ketika ada yang membeli kue tersebut maka yang saya lakukan adalah membantu para pembeli khususnya dalam hal ini membungkuskan kue titipan itu.

Lebih lanjut, jika informan sebelumnya, $t a$ Tini, yang hanya mengambil satu biji kue dari titipan yang beliau terima, maka bagaimanakah dengan ta Mery, keuntungan apa yang beliau dapatkan dari menerima kue tersebut?

Tidak mo rugi ba gitu? [tanya peneliti] ..Tidak, dia mo kase dalapan ratus pa saya, saya mo untung dua ratus kan... Tidak enak kan, biar bagimana juga perasaan kan, biar saja taru jo, nanti adu-adu mujur. InshaaALLAH debo mo laku...Kalau misalnya ti nene itu adakalanya dia mo titip lima puluh.

Tidak merasa rugi? [tanya peneliti]... tidak, penitip memberikan harga Rp 800 kepada saja. Saya untung dua ratus kan... tidak enak juga, biar bagaimana tetap perasaan, terima saja, silahkan diletakan [di meja], nanti beradu kemujuran saja. InshaaALLAH tetap laku... kalau misalnya nenek Raina menitipkan lima puluh biji kue.

Berpijak pada penuturan $t a$ Mery di atas memberikan pemahaman kepada saya bahwa beliau tidak merasa tidak akan mengalami kerugian dengan menerima titipan kue. Hal ini disebabkan penitip memberikan kepada beliau keuntungan Rp 200 dari harga jual kue Rp 1.000. Selain bonus yang diberikan oleh nenek Raina, faktor pendukung lainnya adalah perasaan tidak sampai hati untuk menolak titipan kue. Menurut beliau laku dan tidak kue baik yang beliau buat atau titipan tergantung kemujuran saja. Namun beliau tetap optimis kue-kue tersebut akan tetap laku terjual. Lebih lanjut pada cuplikan wawancara di atas beliau menyatakan bahwa biasanya nenek Raina menitipkan kue sejumlah lima puluh biji.

Amal dari praktik akuntansi konsinyasi di atas adalah "penitip memberikan harga Rp 800 kepada saja. Saya untung dua ratus kan...". Ilmu dari amal ini adalah ketika penitip menitipkan kue kepada saya maka penitip memberikan kuntungan sejumlah Rp 200 per bijinya, sedangkan harga jual kue adalah Rp 1.000. Artinya yang didapatkan oleh penitip dari tiap kue Rp.800. Sebagaimana ketika saya mengamati ta Mary berjualan di lapangan, penitip kue, nenek Raini, dengan kedua tangan yang memegang tempat berisi kue, datang menghampiri jualan kue ta Mery, nenek Rainapun mengatakan jumlah kuenya dan ta Mery mempersilahkan untuk di titip. Dalam pengamatan saya, tidak pernah terjadi tawar-menawar harga titipan di antara kedua. Artinya harga titipan Rp 200 telah diketahui oleh keduanya atau dengan kata lain harga titipan itu telah menjadi pemahaman bersama yang tidak perlu untuk diungkapkan lagi.

Masih pada cuplikan wawancara yang sama, amal berikutnya adalah "nanti beradu kemujuran". IImu dari amal ini adalah saya tidak dapat memastikan bahwa ketika ada yang menitipkan kue kepada saya maka kue jualan saya menjadi tidak laku, atau sebaliknya ketika tidak ada yang menitipkan kue kepada saya maka kue-kue saya justru akan semakin laku. Tidak ada kepastian seperti itu, oleh sebab itu ketika berjualan kue, baik menerima titipan atau tidak menerima titipan yang dilakukan hanya beradu mujur saja. Namun saya tetap berdoa "inshaaALLAH kue-kue ini akan tetap laku terjual". 
Sementara itu, tidak jauh berbeda dengan apa yang dilakukan oleh ta Mery, informan yang lebih lama berjualan dari beliau, $t a$ Nou, menyampaikan hal yang serupa:

Io dia kalau mo ba titip, dua puluh lima biji, dua puluh lima biji, dua puluh ribu pa dorang, torang punya yang mo ba jaga lima ribu, bagitu, jadi ada potongan, kalau misalnya orang kase manumpang lalampa, keyabo... kita mo tarima, supaya itu kuekue yang ta jejer itu dorang mo lia, mana yang dorang mo suka, jadi orang itu alhamdulillah.

Iya kalau ada yang menitip kue, dua puluh lima biji, Rp 20.000 menjadi bagian mereka, sementara kami yang dititipkan diberi Rp.5.000. Begitu jadi ada potongan, kalau misalnya ada yang menitipkan kue lalampa, keyabo dll, saya akan terima agar kue-kue yang terjejer itu ada yang bisa dilihat oleh pembeli, mana yang mereka suka. Jadi orang itu alhamdulillah [ada banyak pilihan kue].

Cuplikan wawancara $t a$ Nou di atas memberikan saya pemahaman bahwa beliau menerima jika ada yang mau menitipkan kue. Lebih lanjut beliau menjelaskan bahwa ta Nou mendapatkan keuntungan Rp 5.000 dari total dua puluh lima kue yang terjual, atau setiap kue yang dijual Rp 1.000 di pasar maka Rp 800 menjadi keuntungan pembuat kue dan Rp 200 kepada penitip. Beliau juga merasa bersyukur karena jika ada yang menitipkan kue berarti semakin banyak juga pilihan kue yang nantinya akan dibeli oleh pembeli.

Ditemukan amal dari praktik akuntansi konsinyasi di atas adalah "dua puluh lima biji, Rp 20.000 menjadi bagian mereka, sementara kami yang dititipkan diberi Rp.5.000". Ilmu dari amal ini adalah keuntungan yang didapatkan jika menerima titipan kue dan kue tersebut laku terjual adalah Rp.200 per biji, artinya walaupun kue-kue tersebut telah diterima namun tidak ada satupun yang terjual, maka penjual tidak akan mendapatkan keuntungan. Hal ini sebagaimana pengamatan yang saya temui dilapangan bahwa setelah berjualan penjual memberitahu jumlah kue yang tersisa dan berpatokan pada jumlah kue yang tersisa itu penitip memberikan jumlah biaya penitipan kepada si penjual. Menerima titipan kue tanpa saling memberitahu lagi syarat dan biayanya merupakan tindakan yang telah memiliki pemahaman bersama antara penjual dan penitip kue.

Masih pada cuplikan wawancara yang sama ditemukan amal "akan terima agar kue-kue yang terjejer itu ada yang bisa dilihat oleh pembeli". Ilmu dari amal ini adalah jika ada pembuat kue yang mau menitipkan kuenya di tempat jualan saya maka yang akan saya lakukan adalah menerimanya. Semakin banyak kue di tempat jualan saya maka semakin banyak pula jenis kue yang bisa dipilih oleh pembeli.

Hal lain yang tidak kalah menarik untuk diketahui adalah jika menerima kue titipan dan tidak mengambil untung tindakan tersebut, lantas apakah informan tidak merasa takut jika nanti kue penitip lebih disukai dibanding dengan kue yang beliau buat? Berikut jawaban ta Tini:

Tidak, bekeng apa, maksudnya, jangan kase-kase banyak, maksudnya kalau so abis, baru bekeng lagi, bagitu juga disini kita, kita mo lia ka sana, mo lia ka sana tinggal sadiki somo ba bekeng poli, itu orang lain itu ta sisa-sisa banyak itu dia somo tumpuk satu kali, kita punya bagitu, kita tidak mo ini samua.

Tidak, buat apa merasa takut, maksudnya jangan di buat banyak-banyak [kuenya]. Nanti kalau sudah habis, baru dibuat lagi. Kalau saya liat kue yang saya jual tinggal sedikit, saya sudah akan membuatnya lagi. Kue pedagang lain sering tersisa banyak disebabkan mereka sering menumpuk [membuat kue dalam jumlah yang banyak]. Punya saya seperti itu, saya tidak akan membuat sekaligus banyak.

Berdasarkan pada penuturan ta Tini di atas di pahami bahwa beliau tidak merasa takut jika jualan beliau tidak laku karena adanya kue lain yang dititipkan di tempat beliau. Justru ta Tini memiliki strategi tersendiri agar jualan belaiu tidak rugi ketika beliau berjualan. Strategi beliau 
berupa tidak membuat kue dagangan (misalnya pisang goreng) sekaligus, akan tetapi disesuaikan dengan jumlah kue yang ada. Jika di lihat kue yang ada tinggal sedikit maka beliau membuatnya lagi.

Cuplikan wawancara di atas terdapat amal praktik akuntansi konsinyasi adalah "jangan di buat banyak-banyak". Ilmu dari amal ini adalah cara agar jualan saya tidak rugi adalah tidak membuat kue sekaligus dalam jumlah yang banyak, jumlah kue menyesuaikan dengan permintaan dari pembeli. Sebagaimana dengan pengamatan saya ketika $t a$ Tini berjualan, kue-kue yang beliau buat dan sediakan di tempat jualan memang tidaklah sebanyak penjual lainnya, beliau akan membuatnya lagi jika ada pesanan. Amal berikutnya adalah "nanti kalau sudah habis, baru dibuat lagi". Ilmu dari amal ini adalah cara lain untuk menghindari kerugian terutama kue dagangan yang tidak habis terjual adalah melihat jumlah kue yang diletakan di meja jualan, apakah kue tersebut tersisa sedikit atau bahkan mungkin habis, jika memang demikian maka barulah ta Tini membuat kembali kuenya. Masih pada informan yang sama yaitu ta Tini, beliau lebih lanjut menuturkan bahwa:

Cuman kalau ada orang yang ba tanya, somo bilang ka sana, io ada...bagitu, mo tanya kalau bo pisang goreng, ada, kita mo bilang ka sana, tunggu a, ini ada balangga dua tataru ini hehehehe, dua balangga kita mo ini, capat to. ...yang penting orang so tau, masih ada ini, kita mo blang io ada, bo kita mo bilang tunggu dulu, lagi mo tunggu, io mo tunggu, lagi mo goreng, dorang suka olo masi panas-panas

Namun kalau ada yang menanyakan kue milik saya [yang pada saat itu sudah habis]. Saya akan menjawabnya masih ada. Misalnya yang menanyakan pisang goreng, saya menjawab ada, tapi saya meminta untuk menunggu, karena saya masih akan menggorengnya hehehe. Saya mempunyai dua wajan yang besar, jadi kalau memesan banyak pisang goreng, bisa cepat selesai... yang penting orang sudah tahu, masih ada kue yang akan dijual. Saya hanya akan menyampaikan silahkan menunggu, mereka [pembeli] juga akan menunggu kue tersebut digoreng. Mereka juga suka [memakan] kue yang masih panas.

Penuturan ta Tini di atas memberikan pemahaman kepada saya tentang cara menjual kue dagangan yang beliau praktikan. Jika kue tersebut habis sementara pembeli menanyakan kue tersebut, maka ta Tini akan mengatakan bahwa kue tersebut masih ada, namun ta Tini akan menanyakan apakah pembeli tersebut bersedia untuk menunggu atau tidak. Jika bersedia maka $t a$ Tini akan membuatkan kue tersebut, terlebih lagi menurut beliau pembeli kue lebih menyukai kue yang masih dalam keadaan hangat dibanding sudah dingin.

Pada cuplikan wawancara di atas terdapat cara praktik akuntansi konsinyasi (amal) berupa "kalau ada yang menanyakan kue saya [yang pada saat itu sudah habis]. Saya akan menjawabnya masih ada" Amal ini memiliki makna pemahaman bersama (ilmu) antara penjual dan pembeli berupa memang kue yang disediakan di tempat jualan telah habis terjual. Namun bukan berarti pada saat yang sama penjual tidak sementara/akan membuatnya lagi. Meskipun melihat kue yang sudah habis di tempat jualan, pembeli akan tetap menanyakan apakah kuenya masih tersedia atau tidak. Hal ini dimaksud untuk mengonformasi kepada penjual apakah penjual masih sementara/mau membuatnya lagi. Jika penjual menjawab masih "ada" itu berarti kue tersebut sementara/akan dibuat. Namun jika kue tersebut telah habis dan ta Tini tidak sedang menggorengnya, maka lebih lanjut $t a$ Tini akan mengonformasi ke para pembeli apakah mereka akan menunggunya atau tidak. Sebagaimana pengamatan saya, rata-rata pembeli justru lebih suka ketika kue misalnya pisang goreng itu akan dibuat lagi, karena mereka lebih memilih gorengan yang hangat/panas dibandingkan yang sudah dingin. Gorengan yang masih panas adalah hal berikutnya yang menjadi keunggulan jualan kue $t a$ Tini dibanding dengan kue yang dititipkan oleh pembuat kue.

Mirip dengan keyakinan akan tidak takutnya para penjual kue tentang pembeli lebih tertarik kue yang dititipkan dari pada kue buatan mereka, ta Mery juga menyampaikan hal yang serupa bahwa memang rata-rata pembeli lebih menyukai kue yang hangat dibandingkan dengan yang sudah dingin, lebih jelas mengenai hal ini dapat dilihat pada cuplikan wawancara beliau berikut: 
Jadi kalau so lia ka sana posisi kurang sadiki kue, kurang lagi mo goreng. Jadi dorang kan cuman suka panas-panas. Kalau dingin dorang so tidak mau itu. Bagitu olo sabongi, kue-kue sabongi. Itu masih mo di gulung kan itu, nanti mo di gulung di pasar itu.

Jadi kalau sudah diliat posisi kue kurang sedikit, maka akan digoreng lagi, jadi mereka [pembeli] kan cuman suka yang panas-panas. Kalau dingin mereka sudah tidak mau. Begitu juga kue sabongi, kue itu masih digulung kan, nanti digulung di pasar itu.

Cuplikan wawancara $t a$ Mery di atas memberikan saya pemahaman bahwa apa yang beliau lakukan mirip dengan ta Tini lakukan, beliau tidak menggoreng kue dalam jumlah yang banyak akan tetapi didasarkan pada jumlah kue yang beliau letakan di meja, jika jumlah kue-kue tersebut tersisa sedikit, maka beliau akan menggoreng kue yang baru lagi, sehingga kecil kemungkinan kue buatan beliau akan tersisa banyak. Sementara itu beliau tidak merasa takut jika kue yang beliau buat tidak akan diminati oleh pembeli karena memang salah satu keunggulan berjualan sendiri adalah beliau dapat menyuguhkan kue yang masih hangat.

Berpijak pada penurutan ta Mery di atas ditemukan amal dari praktik akuntansi konsinyasi berupa “jadi kalau sudah diliat posisi kue kurang sedikit, maka akan digoreng lagi”. Ilmu dari amal ini adalah saya tidak akan menggoreng semua kue dalam jumlah yang banyak, namun saya akan menyesuaikan dengan jumlah yang tersedia di meja jualan. Jika jumlah itu tinggal sedikit maka saya akan menggoreng kue yang baru lagi. Tindakan beliau sama dengan apa yang ta Tini lakukan juga. Amal berikutnya adalah "kue itu masih digulung kan, nanti akan digulung di pasar itu" Ilmu dari amal ini adalah kue-kue yang saya jual di pasar Kamis adalah kue yang saya goreng di tempat tersebut, sesudah saya merapikan tempat jualan saya barulah kemudian saya membuat adonan kue yang nanti akan saya goreng dan jual kepada penjual.

Hal berbeda justru dilakukan oleh ta Nou, dimana beliau menuturkan bahwa ketika ada pembeli kue yang dititipkan kepada beliau, beliau justru menambah kue yang diambil dari kue buatan beliau. Berikut cuplikan wawancaranya:

Adakalanya kita kalau memang, kita pikir ka sana, kalau dorang umpama somo ba bili umpama spulu biji, tetap kita mo ba tamba, tapi kita mo ba tamba bukang kite pe kue yang di titip itu. Kita pe kue yang kita mo ambe. Karna kita mo pancing akan pa dorang. Langganan mo maso, itu yang kita pe cara dengan dorang.

Terkadang kalau mereka misalnya membeli kue sepuluh biji, tetap saya akan menambahnya, tapi yang di tambah dengan kue saya, bukan kue yang dititip itu. Saya mengambil kue saya untuk ditambah. Saya gunakan untuk memancing mereka. Langganan untuk masuk, begitu cara saya dengan mereka.

Cuplikan wawancara ta Nou di atas dipahami bahwa terkadang ketika ada pembeli yang membeli kue yang dititipkan kepadanya, tindakan beliau justru memberikan bonus kue kepada pelanggan tersebut. Kue bonus itu bukanlah diambil dari kue si penitip akan tetapi dari kue yang beliau buat, beliau menuturkan itu merupakan salah satu strategi beliau untuk memikat pelanggan.

Berpijak pada pernyataan $t a$ Nou di atas ditemukan amal praktik akuntansi konsinyasi berupa "Terkadang kalau mereka misalnya membeli kue sepuluh biji, tetap saya akan menambahnya, tapi yang ditambah dengan kue saya". Ilmu dari amal ini adalah ketika ada pembeli membeli kue yang dititipkan kepada saya terkadang tindakan saya adalah memberikan bonus kue kepada pembeli, kue bonus itu tidaklah diambil dari kue yang dititipkan akan tetapi diambil dari kue buatan saya. Amal berikutnya adalah "Saya gunakan untuk memancing mereka". Ilmu dari amal ini adalah salah satu cara saya agar baik jualan saya maupun titipan yang diamanahkan kepada saya tetap laku terjual adalah dengan menambahkan bonus kue kepada setiap pembeli. Hal ini dilakukan agar kue di tempat jualan saya habis terjual dan juga bersamaan dengan itu saya berharap tindakan tersebut dapat menarik minat pelanggan. 


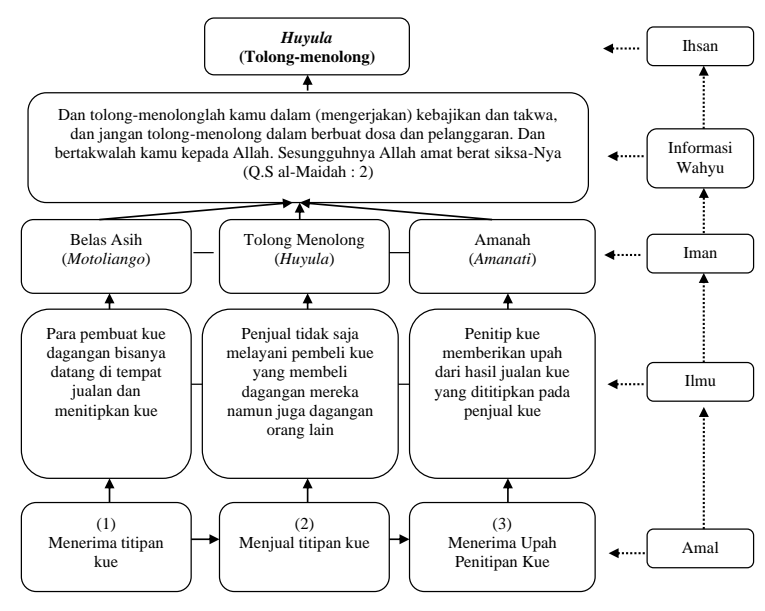

Gambar 1. Analisis Praktik Akuntansi Konsiyasi Melalui Pendekatan Etnometodologi Islam

Pada pembahasan di atas telah ditemukan amal praktik akuntansi konsinyasi berupa menerima titipan kue, kemudian menjualnya dan terakhir menerima upah dari penitipan kue. Setiap amal telah dijelaskan oleh ilmu. Amal pertama menerima titipan kue. Makna rasional dari amal ini adalah para pedagang kue biasanya menerima pembuat kue yang ingin menitipkan barang dagagangn di tempat mereka. Selanjutnya amal kedua menjual titipan kue. Amal ini memiliki makna rasional bahwa penjual kue yang berada di pasar kamis tidak saja melayani pembeli yang ingin membeli barang dagangan mereka tetapi juga pembeli yang ingin membeli barang titipan penjual kue. Amal ketiga adalah menerima penitipan kue. Penitip kue akan memberikan imbalan jasa kepada penjual yang mau menerima kue titipan. Cara pemberian upah ini telah dijelaskan diawal ketika penitip pertama kali menitipkan barang kepada penjual. Sehingga dihari-hari pasar berikutnya, penitip hanya tinggal mengantar kue-kue titipan kepada penjual sekaligus menyebutkan jumlah kue tersebut.

Terdapat tiga nilai budaya Islam gorontalo yang menggerakkan praktik akuntansi konsinyasi di atas (iman). Ketiga nilai tersebut adalah nilai belas asih (motolianga), tolong-menolong (huyula) dan amanah (amanati). Nilai belas asih ini tercermin dari ungkapan para informan di atas bahwa mereka merasa tidak tega untuk menolak ketika ada penjual kue yang ingin menitipkan barang dagangan. Sementara nilai tolong- menolong (huyula) tercermin lewat para pedagang yang melayani pembeli yang tidak saja ingin membeli barang dagangan mereka tetapi juga titipan dari pedagang lainnya. Dan juga pedagang kue (khususnya ta Tini) yang tidak ingin mengambil keuntungan dari jasa penitipan kue yang telah ia berikan. Nilai terakhir yaitu amanah (amanati) tercermin lewat penjual kue yang memberikan bonus tambahan kue kepada pembeli yang membeli kue titipan, menariknya bonus kue tersebut diambil dari kue jualan milik dari si pemilik.

Baik nilai belas asih, tolong-menolong dan juga amanah merupakan cerminan dari pengimplementasin dari filosofi budaya Islam Gorontalo yaitu adat bersendikan syarah, syarah bersendikan kitabullah (Adat berdasarkan pada syariat dan syariat berdasarkan kepada Alquran dan juga hadis). Kebudayaan di Gorontalo didasarkan pada nilai-nilai agama Islam oleh sebab itu segala aspek kehidupan masyarakat setempat berpedoman pada Al-Quran dan juga hadist.. Nilai belas asih, tolong menolong dan juga amanah merupakan salah satu perintah Tuhan yang tertulis dalam informasi wahnya-Nya yaitu Q.S al-Maidah ayat 2 "Dan tolong-menolonglah kamu dalam (mengerjakan) kebajikan dan takwa, dan jangan tolong-menolong dalam berbuat dosa dan pelanggaran. Dan bertakwalah kamu kepada Allah. Sesungguhnya Allah amat berat siksa-Nya".

Tolong-menolong (huyula) merupakan alasan utama dari pertanyaan mengapa pedagang pasar tradisional mempraktikkan akuntansi konsinyasi. Tolong-menolong ini menjadi motif utama para pedagang, hal tersebut dapat dilihat dari tindakan mereka yang tetap mau menerima barang titipan sekalipun biaya yang diberikan oleh para pedagang tidaklah seberapa (Rp 200). Selain itu, terdapat juga pedagang yang rela memberikan bonus kue tambahan. Kue tambahan tersebut diambil dari kue jualannya sendiri, kemudian ditambahkan kepada pembeli yang membeli kue 
titipan. Bahkan diantara pedagang ada yang tidak ingin mengambil keuntungan (menerima bonus) dari setiap hasil penjualan kue yang dititipkan. Hal ini disebabkan oleh keadaan mereka yang kurang lebih sama-sama membutuhkan uang. Jika setiap kali penitip kue dimintakan upah, lalu berapa hasil yang akan penitip kue akan dapatkan? Berpijak pada kondisi ini maka tidaklah berlebihan mengatakan bahwa ihsan atau alasan utama mengapa pedagang pasar tradisional mempraktikkan akuntansi konsinyasi adalah karena semangat tolong-menolong (huyula).

Berangkat dari temuan tentang praktik akuntansi konsinyasi oleh pedagang pasar kamis di atas, maka langkah selanjutnya saya mengkonstruksi praktik akuntansi konsinyasi tersebut berdasarkan kecerdasan intelektual, emosional, spiritual dan sosial yang dapat dilihat pada gambar berikut ini:

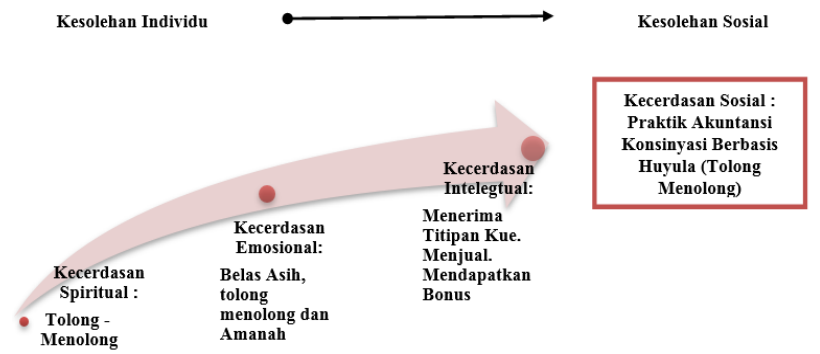

Gambar 2. Huyula: Konstruksi Akuntansi Konsiyasi Berbasis Kecerdasan Intelektual, Emosional, Spiritual, dan Sosial

Pada gambar kostruksi di atas, kecerdasan intelektual, emosional dan spiritual merupakan kecerdasan yang berada dalam diri seseorang. Ketiga kecerdasan ini saya sebut dengan kesolehan individu. Sementara itu kecerdasan sosial merupakan output yang dihasilkan dari kecerdasan dalam diri dan mendatangkan manfaat serta kebaikan bagi sosial atau kesolehan sosial.

Pada kesolehan individu dimulai dari kecerdasan yang paling dalam yaitu spiritual. Kecerdasan ini merupakan ruh yang menjiwai setiap gerak individu. Sebagaimana temuan pada analisis etnometodologi Islam di atas bahwa huyula (tolong menolong) sebenarnya ruh yang menggerakkan praktik akuntansi konsinyasi. Sementara itu masih fokus pada individu itu sendiri, terdapat kecerdasan emosional berupa rasa belas asih terhadap sesama, amanah ketika berjualan dan juga tolong menolong. Kedua kecerdasan yaitu spiritual dan emosional dapat dipahami dengan menggunakan intuisi.

Berdasarkan tiga rasa emosional yang ditemukan maka dibentuk praktik akuntansi konsinyasi yang dapat dipahami oleh kecerdasan intelektual (akal) berupa cara mempraktikkan akuntansi konsinyasi. Ditemukan tiga cara praktik akuntansi konsinyasi yaitu pertama menerima barang titipan, kedua menjual dan ketiga menerima bonus dari penjualan. Meskipun ketiga alur yang terbentuk dari praktik akuntansi konsinyasi di pasar tradisonal mirip dengan akuntansi konsinyasi modern. Namun patut digarisbawahi bawah ketiga alur tersebut digerakkan dengan semangat yang berbeda. Akuntansi konsinyasi yang dipraktikkan oleh pedagang pasar tradisional digerakkan oleh kecerdasan spiritual tolong-menolong bukan mencari keuntungan materi semata. Sementara itu juga, akuntansi konsinyasi versi pedagang pasar tradisional hadir karena adanya rasa kemanusiaan antara sesama bukan sebatas kepentingan pribadi (self interest).

Ketiga kecerdasan yang dimiliki dalam diri tersebut pada akhirnya menggiring pada kecerdasan sosial (amal sosial) dalam hal ini praktik akuntansi konsinyasi berbasis tolongmenolong (huyula). Artinya akuntansi konsinyasi yang dipraktikkan oleh pedagang pasar tradisional sebenarnya merupakan bentukan dari empat kecerdasan manusia yaitu kecerdasan spiritual, emosional, intelektual dan sosial. Dan tolong-menolong (huyula) merupakan nilai yang menjadi dasar dari praktik akuntansi konsinyasi oleh pedagang pasar tradisional di Gorontalo.

\section{KESIMPULAN}

Berdasarkan pembahasan di atas maka dapat disimpulkan bahwa ditemukan tiga cara praktik akuntansi yang terekam dalam analisis amal. Ketiga cara tersebut adalah pertama menerima titipan kue, kedua menjual kue titipan, ketiga menerima bonus. Ketiga amal ini memiliki penjelasan 
rasional (ilmu). Pertama, penjelasan rasional untuk amal pertama yaitu menerima titipan kue, penjual kue yang biasanya datang ketempat penjual kue dan menitipkan dagangan mereka. Kedua, penjelasan untuk amal kedua adalah penjual kue di pasar tradisional tidak saja menjual kue hasil jualan mereka namun juga kue dagangan dari pihak penitip. Ketiga, selanjutnya penjelasan untuk amal ketiga adalah penitip kue memberikan upah dari hasil jualan kue kepada penjual yang bersedia menerima titipan kue mereka.

Sepintas apa yang ditemukan dilapangan mirip dengan apa yang dipraktikkan oleh akuntansi konsinyasi modern. Namun ternyata praktik akuntansi konsinyasi yang ditemukan lewat amal dan juga ilmu dipasar tradisional Gorontalo memiliki nilai yang berbeda dengan akuntansi modern. Nilai pembeda tersebut ditemukan lewat analisis iman atau nilai-nilai budaya yang menggerakkan akuntansi konsinyasi. Nilai-nilai budaya tersebut adalah pertama belas asih (motoliango), tolongmenolong (huyula), amanah (amanati). Ketiga nilai ini merupakan implementasi dari filosofi budaya Islam Gorontalo yaitu adat bersendikan syarah, syarah bersendikan kitabullah (Adat berdasarkan pada syariat dan syariat berdasarkan kepada Alquran dan juga hadis).

Ketiga nilai yang ditemukan juga sejalan dengan informasi wahyu dalam Q.S al-Maidah. Direnungkan lebih jauh lagi ditemukan bahwa ihsan atau alan mengapa pedagang pasar tradisional mempraktikkan akuntansi konsinyasi adalah karena semangat tolong menolong (huyula). Berpijak pada hasil temuan ini kemudian dikonstruksi akuntansi konsinyasi berdasarkan pada kecerdasan spiritual, emosional, intelektual dan sosial. Sehingga menghasilkan akuntansi konsinyasi berbasis tolonh-menolong (huyula).

\section{DAFTAR PUSTAKA}

Ahmar, N., \& Kamayanti, A. (2009). Exploring Accounting and Its Perseverance in Javanese Ceremonies ( Slametan ) Through Hermeneutic-Phenomenological Study. Simposium Nasional Akuntansi (SNA) XII. Palembang, 2-9 November., 1-22.

Amaliah, T. H. (2014). Konsep Penetapan Harga Jual Papalele dalam Lingkup Nilai-Nilai Budaya Masyarakat Maluku. Brawijaya.

Botutihe, M., \& Daulima, F. (2003). Tata Upacara Adat Gorontalo. Gorontalo: Forum Suara Perempuan.

Daulima, F. (2004). Aspek-Aspek Budaya Masyarakat Gorontalo. Limboto: Banthayo Pobo'ide Fitrah.

Daulima, F. (2006). Ragam Upacara Tradisional Daerah Gorontalo. Gorontalo: Forum Suara Perempuan.

Jasin, J. (2015). Value In Executing Tumbilo Tohe ( Pairs Of Lights ) Each End Of Ramadan As One Manifestation Of The Practice Of Pancasila By People Of Gorontalo. Journal of Humanity, 3(1), 1-13. https://doi.org/10.14724/03.01

Kamayanti, A. (2015a). Metode Penelitian "Kualitatif” (Sepucuk Surat Untuk Tuhan ). In Disajikan untuk Workshop Metode Penelitian di Universitas Mercu Buana, Jakarta, 25-27 Agustus 2015 (pp. 25-27). Jakarta: Disajikan untuk Workshop Metode Penelitian di Universitas Mercu Buana, Jakarta, 25-27 Agustus 2015.

Kamayanti, A. (2015b). "Sains" Memasak Akuntansi: Pemikiran Udayana dan Tri Hita Karana. Jurnal Riset Dan Aplikasi: Akuntansi Dan Manajemen, 1(2), 73-80. https://doi.org/10.18382/jraam.v1i2.16

Kamayanti, A. (2016). Metodologi Penelitian Kualitatif Akuntansi Pengantar. Jakarta Selatan: Yayasan Rumah Peneleh.

Kuntowijoyo. (2007). Islam Sebagai Ilmu: Epistemologi, Metodologi, dan Etika. Jakarta Selatan: Teraju. 
Ludigdo, U. (2004). Mengembangkan Pendidikan Akuntansi Berbasis IESQ untuk Meningkatkan Perilaku Etis Akuntan. TEMA, 5, 134-149.

Martadinata, Su. (2015). Mengungkap Makna Kekayaan "Istana dalam Loka.” Tesis. Brawijaya.

Mulawarman., Aji Dedi, Ludigdo, U. (2010). Metamorfosis Kesadaran Etis Holistik Mahasiswa Akuntansi Implementasi Pembelajaran Etika Bisnis Dan Profesi Berbasis Integrasi Iesq. Jurnal Akuntansi Multiparadigma, 1, 421-436.

Mulawarman, A. D. (2013). Nyanyian Metodologi Ala Nataatmadja: Melampaui Derridian Mengembangkan Pemikiran Bangsa "Sendiri." Jurnal Akuntansi Multiparadigma, 4(1), 149164. Retrieved from www.jamal.ub.ac.id

Randa, F., Triyuwono, I., Ludigdo, U., \& Sukoharsono, E. A. (2011). Studi etnografi: akuntabilitas spiritual pada organisasi gereja katolik yang terinkulturasi budaya lokal. Jurnal Akuntansi Multiparadigma.

Sardar, Z. (1985). Masa Depan Islam. Bandung: Penerbit Pustaka.

Thalib, M. A. (2014). Dimanakah pancasila kini berada? sebuah tinjauan krisis terhadap kode etik akuntan publik indonesia. Media Mahardhika, 13, 27-36.

Thalib, M. A. (2016). The importance of Accounting Investigation in Wedding Ceremony in Gorontalo. Imperial Journal of Interdisciplinary Research (IJIR), 3(1), 420-428.

Thalib, M. A. (2017). Akuntansi "Cinta" Di Upacara Pernikahan Gorontalo, Studi Etnometodologi Islam. Brawijaya.

Thalib, M. A., \& Prasindi, G. (2016). Sajadah Cinta Manajemen Risiko Syariah. In Ekonomi Syariah Dalam Pemberdayaan Sektor Riil Di Indonesia (pp. 34-45). Malang.

Triyuwono, I. (2006a). Akuntansi Syari'ah: Menuju Puncak Kesadaran Ketuhanan Manunggaling Kawulo Gusti. Pidato Pengukuhan Guru Besar.

Triyuwono, I. (2006b). Perspektif, Metodologi, dan Teori Akuntansi Syariah. Jakarta: PT Raja Grafindo Perseda.

Triyuwono, I. (2011a). "Sususaya" Melampaui Paradigma-Paradigma Metodologi Penelitian. Accounting Research Training Series 2.

Triyuwono, I. (2011b). Angels Sistem Penilaian Tingkat Kesehatan Bank Syariah. Jurnal Akuntansi Multiparadigma.

Triyuwono, I. (2011c). Mengangkat "Sing Liyan" untuk Formulasi Nilai Tambah Syari'ah. Jurnal Akuntansi Multiparadigma. https://doi.org/http://dx.doi.org/10.18202/137

Triyuwono, I. (2013). [Makrifat] Metode Penelitian Kualitatif [dan Kuantitatif] untuk Pengembangan Disiplin Akuntansi. Simposium Nasional Akuntansi, (September), 1-15. https://doi.org/10.1017/CBO9781107415324.004

Triyuwono, I. (2015a). Akuntansi Malangan: Salam Satu Jiwa dan Konsep Kinerja Klub Sepak Bola. Jurnal Akuntansi Multiparadigma, 6(2), 290-303. https://doi.org/http://dx.doi.org/dx.doi.org/10.18202/jamal.2015.08.6023 Jurnal

Triyuwono, I. (2015b). Filosofi Tauhid: Mendekonstruksi Pendidikan Akuntansi Syariah yang Sekuler. Workshop Nasional Kurikulum Akuntansi Sayriah, 6-7. 
Wiyarni, Triyuwono, I., Ludigdo, U., \& Djamhuri, A. (2013). Javanese Traditional Market Cultural Value in Accounting World, 10(5), 9-16.

Yunus, R. (2013). Transformasi Nilai-Nilai Budaya Lokal Sebagai Upaya Pembangunan Karakter Bangsa (Penelitian Studi Kasus Budaya Huyula di Kota Gorontalo). Jurnal Penelitian Pendidikan, 14(1), 65-77. 